\title{
POSTMORTAL DIAGNOSIS OF TOXOPLASMOSIS IN CATS AND DOGS
}

M. SVOBODA, K. HEJLICEK, P. NEUHYBEL, O. JELINEK and L. BERÁNEK

Department of Diagnostics, Therapy and Control of animal Diseases, University of Veterinary Science, 61242 Brno

Received August 7, 1987

A b s $t r a c t$

$S$ v $\circ$ b o d a M.,

K. He j 1 i č e k,

P. N e u -

h y b e 1 , 0. J e l i n e k, L. B e r án e k: Postmortal Diagnosis of Toxoplasmosis in Cats and Dogs. Acta vet. Brno, 57, 1988: 31-38.

Post-mortem examination for toxoplasmosis was carried out on 161 cats and 101 dogs that died or were euthanatized at the clinic of small animal diseases of the University of Veterinary Science, Brno, during a 5-year period. Microscopic examination of compression preparations of various portions of the brain and subsequent staining demonstrated tissue cysts of Toxoplasma gondii in $4(2.48 \%)$ cats. Isolation attempts on toxoplasma-negative white mice were evaluated in 150 cats and 101 dogs. The presence of $T$. gondii was demonstrated in $17(11.33 \%)$ cats up to 3 years of age and in one $(0.99 \%)$ dog aged 8 years. The largest numbers of $T$. gondii were isolated from the brain, heart and liver. Gross miliary necroses in the liver were found in 2 cats.

Demonstration of the developmental stages of $\underline{T}$. gondii by isolation attempts on toxoplasma-negative white mice proved several times more efficient than microscopic examination of compression preparations of various portions of the brain and examination for gross changes in the liver.

Toxoplasma gondii tissue cyst, isolation attempts, compression preparations, brain.

Postmortal diagnosis of toxoplasmosis in cats and dogs is rather difficult to make. It is based primarily on demonstration of the causative agent, Toxoplasma gondii, in the tissues of animals that died or were euthanatized. Pathomorphological changes are often absent or are considerably variable and non-specific ( $\mathrm{N}$ e b e r 1 e and $\mathrm{C} \circ \mathrm{h}$ r 1970; M e i g a s s $\mathrm{n}$ e $\mathrm{r}$ et al. 1977).

W a $\mathbf{r}$ et al. (1971) found pathological changes mainly in the CNS. In naturally infected cats they demonstrated foci of chronic cerebral inflammation and tissue cysts of $T$. gondii. B o c h (1973) fourd tissue 


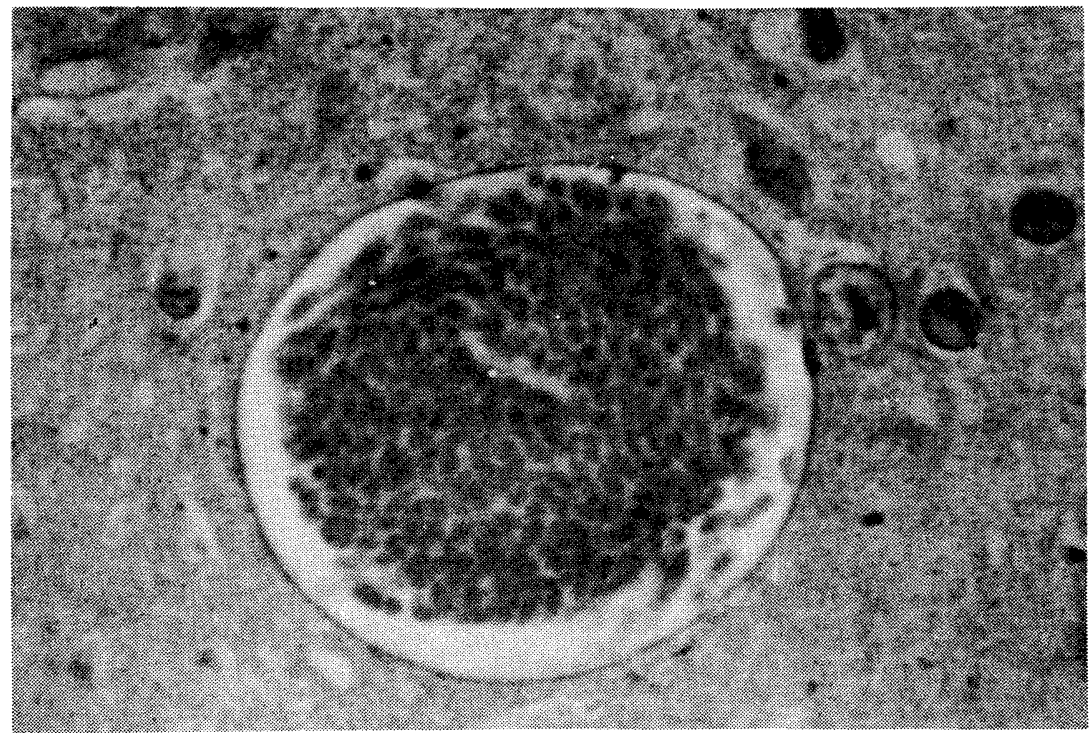

Fig. 1. Detail of a tissue cyst of Toxoplasma gondii in the brain (magnification: objective $\times 45$, ocular $\times 10$ ).

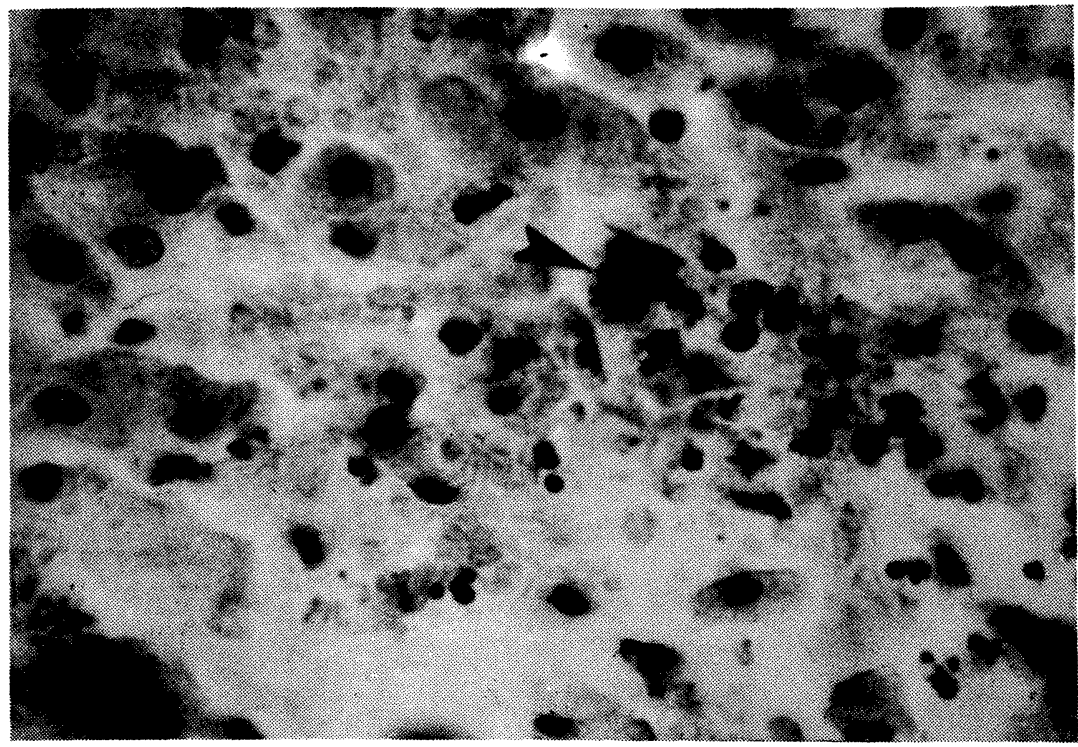

Fig. 2. Pseudocysts of Toxoplasma gondii in the 1iver. Haematoxylin and eosin (magnification: objective $\times 45$, ocular $\times 10$ ). 


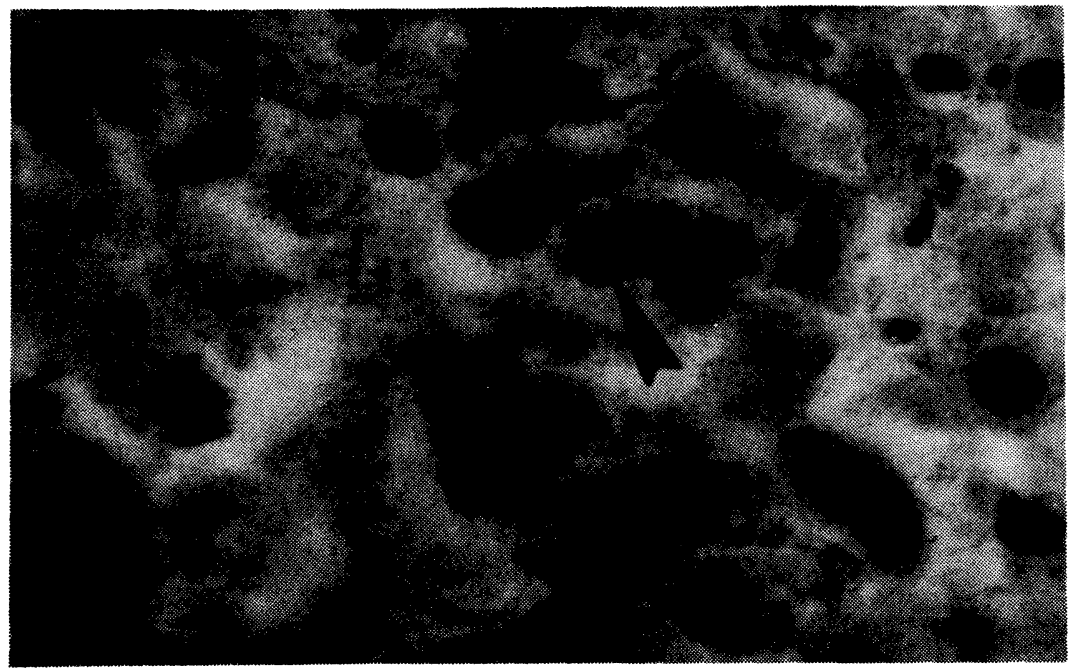

Fig. 3. Pseudocysts of Toxoplasma gondii in the liver. Haematoxylin and eosin (magnification: objective $\times 45$, ocular $\times 10$ ).

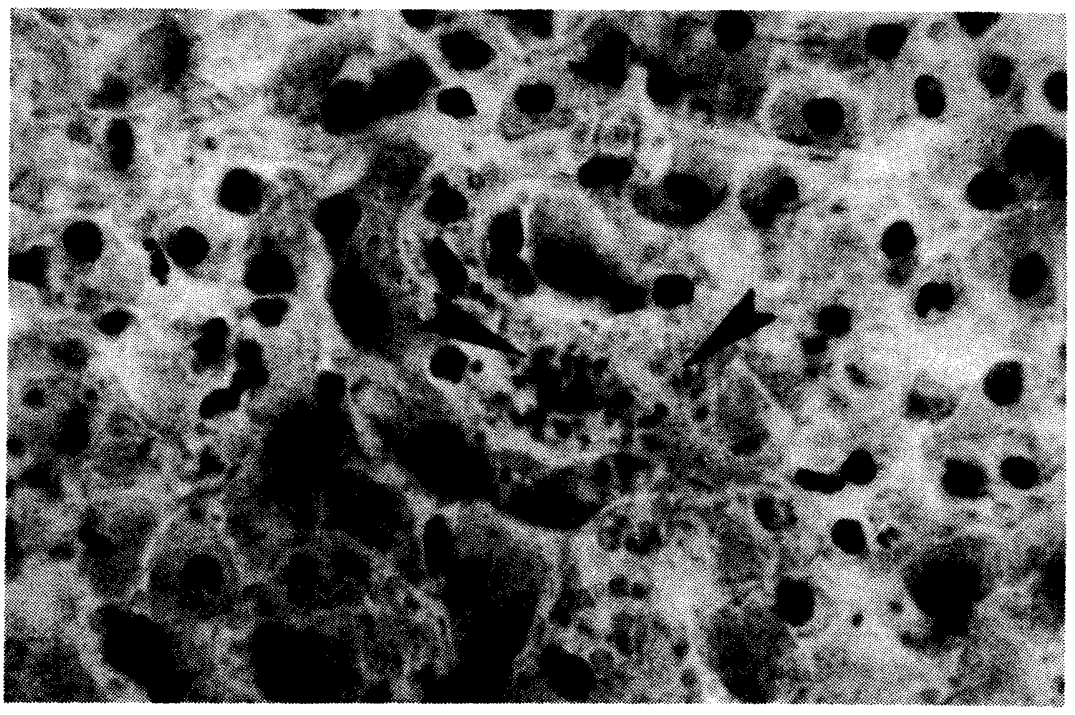

Fig. 4. Liver tissue with free zoites of Toxoplasma gondii. Haematoxylin and eosin (magnification: objective $\times 45$, ocular $\times 10$ ). 
cysts mainly in the brain, heart and diaphgram. Having infected specific-pathogen free cats experimentally by i.v. administration of tachyzoites, P a $\mathrm{r}$ e $\mathrm{r}$ et al. (1981) demonstrated multifocal necroses with large numbers of the parasites in non-lymphatic organs. The spleen and mesenteric lymph nodes showed reticuloendothelial and lymphoid hyperplasia with small numbers of $\underline{T}$. gondii. Changes in the lung were the first to occur and were also the main cause of the animal's death. D $u$ $b$ e $y$ and $J o h n s t o n$ e (1982) described pathological findings in 3 kittens that died or were euthanatized between 16 and 32 days after birth. They found diffuse interstitial pneumonia and multiple necroses in the liver.

A study on post-mortem examination for toxoplasmosis in dogs in Hungary was reported by $D \circ b \circ s-K o v a ́ c s$ and $K$ a $r$ d e vá $n$ (1976). During a 3-year period they diagnosed toxoplasmosis 34 times, i.e. in $1.54 \%$ of he dogs subjected to autopsy. Their most frequent findings were focal exudative necrotic pneumonia and miliary necroses in the liver. On histological examination they found a large number of trophozoites in alveolar and bronchial exudate and demonstrated the causative agent also by electron microscopy. $N$ e $s$ b $i$ et al. (1981) described generalized toxoplasmosis in two puppies: The pathological findings were encephalomalacia with degeneration and necrosis. The histological changes decreased in the caudal direction. Tissue cysts were found most frequently in atrophic muscle parts of the hind legs. The suggested that the disease was congenital toxoplasmosis where changes in the CNS and muscles are found rather frequently.

$\mathrm{K} \circ \mathrm{u} \mathrm{b} \mathrm{a}$ et al. (1974) summarized the results of isolation attempts in cats conducted in Czechoslovakia in 1948 - 1970: $T$. gondi were isolated 22 times, in $27.5 \%$ out of 80 cats examined. In Japan, $H$ a $g$ i w a $r$ a (1977) isolated T. gondii in 24.0 to $71.4 \%$ out of 89 cats and in 0 to 14.9 \% out of $4 \overline{30}$ dogs examined in $1957-1970$. B $\circ \mathrm{g} \mathrm{d} \mathrm{a} \mathrm{j} \mathrm{u} \mathrm{k} \mathrm{(1972)}$ and $D i s k o$ et al.(1978) isolated $T$. gondii most frequently from the brain, heart, diaphragm and skeletal muscles. C o s t a et al. (1977), on the other hand, found $T$. gondii most frequently in the lymph nodes. In isolation attempts in chronically T. gondii-infected cats, D u b e y (1977) isolated the parasite more frequently from the heart than from the brain. $\mathrm{P}$ a $\mathrm{r} \mathrm{k}$ e $\mathrm{r}$ et al. (1981), using experimentally infected cats, demonstrated T. gondii in all tissues, but most frequently in the liver, lung and spleen. The object of our study was to compare pathomorphological findings with the results of examination of compression preparations of the brain and with the results of isolation attempts on toxoplasma-negative white mice as to their value for postmortal diagnosis of toxoplasmosis in cats and dogs.

Materials and Method s

A total of 262 cats and dogs that died from various reasons or were euthanatized at the clinic of small animal diseases of the University of Veterinary Science, Brno, were subjected to post-mortem examination during a 5-year period. The sample examined consisted of 161 cats and 101 dogs of both sexes including castrates. They were of various ages and came mostly from the conurbation of Brno.

'Pathological examination was carried out within 24 hours of the animals' death and isolation attempts on toxoplasma-negative white mice were

Pathological examinations were carried out at the Department of Pathomorphology and Parasitology, and ++ isolation attempts were conducted at the Department of Epizootiology and Microbiology of the University of Veterinary Science, Brno. 
started immediately after collection of the samples or during the next 12 hours at the latest.

The organs and tissues of the cats and dogs were first subjected to gross examination. In indicated cases, tissue samples were collected for histological examination. They were fixed in $10 \%$ formol, embedded in paraffin and stained with haematoxylin and eosin. Further microscopic examination focused on demonstration of $T$. gondii in compression preparations was carried out only in cats. Three samples each were obtained from each cat from 6 different sites of the CNS (the left and right hemispheres, cerebellum, medulla oblongata, corpora quadrigemina, diencephalon). Immediately afterwards compression preparations were prepared and examined under a microscope. The brain tissue samples in which $T$. gondii cysts were found were fixed in $10 \%$ formol, stained with haematoxylin and eosin and subjected to further histopathological examination. For differentiation of toxoplasma cysts from sarcocysts, staining with PAS method was employed.

By isolation attempts on toxoplasma-negative white mice a total of 161 cats and 101 dogs were examined. Samples of the brain (from dorsal parts of the hemispheres), liver and spleen were collected from fresh carcases and cut into thin slices. After $20 \mathrm{ml}$ of sterile buffered saline supplemented with antibiotics ( $1 \mathrm{~g}$ STM and 600000 I.U. PNC per $1000 \mathrm{ml}$ of buffered saline) was added, the slices were homogenized in a heavy-wall beaker with an electric immersion stirrer. To prevent mutual contamination of the samples, the rotary part of the stirrer was exchanged after homogenization of each sample. The suspension thus obtained was administered intraperitoneally to mice at the rate of $1 \mathrm{ml}$ per mouse. Generally, a pooled sample (brain + liver + spleen) was prepared from each carcass and administered to 3 mice ( $\mathrm{H} \mathrm{e} j \mathrm{j} i \mathrm{c}$ e $k$ et al. 1981). In 4 cats with previous evidence of $\mathrm{T}$. gondii oocysts in the faeces, samples were obtained, in addition, of the diencephalon, cerebellum, medulla, heart, lung, diaphragm and skeletal muscles. For isolation attempts, these samples were administered separately to 3 mice each so that the presence of $T$. gondii could be assessed in the individual organs. The mice were killed and exsanguinated after 5 weeks unless they died earlier. Three compression preparations of the brain of each mouse were prepared and examined for the presence of $T$. gondii tissue cysts. Blood sera of mice infected with one sample were examined serologically using Sabin-Feldman's dye test (SFT) and the complement-fixation test (CFT) according to standards valid in

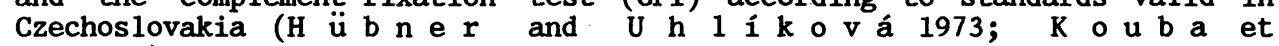
a1. 1974).

\section{R e s u l.t s}

Microscopic examination of compression preparations of the brain tissue demonstrated T. gondii tissue cysts in $4(2.48 \%)$ out of 161 cats between 10 weeks and 1 year of age. In all these cases the cysts were demonstrated in the brain hemispheres (Fig. 1).

Isolation attempts on toxoplasma-negative white mice were started in all the cats but were evaluated in only 150 of them. A total of $33^{\circ}$ mice infected with the material from 11 cats died, for various reasons, before the examination for the presence of $T$. gondii could be completed. By these isolation attempts $\underline{T}$ gondii were demonstrated in 17 
$(11.33 \%)$ out of the 150 cats. The animals ranged between 16 days and 3 years of age and all of them were European short-haired domestic cats (10 females and 7 males). Positive results of $T$. gondii isolation attempts were obtained for all four cats in which tissue cysts were revealed by microscopic examination of compression preparations of the brain. As the mice were injected with pooled samples (brain + liver + spleen) it could not be specified from which organ $T$. gondii were isolated. In the 4 cats in which $T$. gondii oocysts were demonstrated in the faeces before the isolation attempts were started and where separate inoculations from 10 different sites were made the presence of $T$. gondii was demonstrated in all the organs under study. The largest numbers of $T$. gondii were isolated from the brain hemispheres, heart and liver. Antibodies to $T$. gondii in the sera of experimental mice were demonstrated in all 17 instances where cysts were demonstrated in compression preparations of the brain.

Gross evidence pointing to the possibility of acute toxoplasmosis, characterized by irregularly demarcated foci of hepatic necrosis up to $3 \mathrm{~mm}$ in diameter, was found in $2(1.24 \%)$. kittens aged 10 weeks and 4.5 months. Both of them were previously found to excrete $T$. gondii oocysts in the faeces. Fig. 2 and 3 show $T$. gondii pseudocysts (marked with arrows) in the liver and, in the adjacent hepatocytes, dystrophic to necrotic changes of the cells accompanied by pycnosis of the nuclei. Fig. 4 shows liver tissue with free $\underline{T}$. gondii zoites scattered outside the cell structure. In one cat, gross examination revealed also focal gliosis in the CNS and necrosis, mainly monocellular, of the myocardium. In the mucosa of caudal portions of the duodenum and ileum numerous non-sporulated $T$. gondii oocysts were found together with other multiplication stages of the parasite that are difficult to differentiate under an optical microscope. In the remaining 15 cases where $T$. gondii were demonstrated by positive isolation attempts the pathological findings were not specific. This group also includes all 4 cats in which $T$. gondii cysts were found in compression preparations while gross examination of the organs yielded negative results.

Isolation attempts started with the material obtained from 101 dogs that died or were euthanatized yielded positive results in only one $(0.99 \%)$ of them, an 8-year old female Pekinese that died with signs of chronic respiratory distress. Pathological examination of the animal revealed 
chronic interstitial bronchopneumonia affecting two thirds of the lungs, and pulmonary oedema. Neither the brain nor the lungs were subjected to histological examination.

\section{D i s c u s s i o n}

Examination for toxoplasmosis by isolation attempts on toxoplasma-free white mice covering a total of 262 cats and dogs that died or were euthanatized demonstrated $\mathrm{T}$. gondii in $11.3 \%$ of the cats and in $1 \%$ of the dogs. The percentage of positive isolations from cat tissues is slightly lower than that reported by $\mathrm{K} \circ \mathrm{u}$ b a et al. (1974). Positive $\mathrm{T}$. gondii isolations from dogs are substantially less frequent in general and, compared with cats, are very rare. Therefore $1 \%$ of positive isolations in our study is not at variance with the findings reported in our country and abroad (K o u b a et al. 1974; H a g i w a $r$ a 1977).

Although the organs used for examination were obtained from animals that died or were euthanatized not later than 36 hours before the isolation attempts were started and although antibioics were added to the material, 33 mice died in consequence of bacterial contamination with pasteurellas (or possibly other microbes) and organ samples from 11 cats could not therefore be evaluated. This problem was not encountered in dogs.

$T$. gondii is a pantropic parasite which can attack all living cells with the developed nucleus. Theoretically, $T$. gondii could therefore be isolated from all organs and tissues except mammalian erythrocytes. In view of the pathogenesis of the process and with regard to the data on $\mathrm{T}$. gondii isolations from individual organs ( $B$ o $g$ d a $n j \bar{k}$ 1972; $\mathrm{H}$ e $j \mathrm{l}$ í č e $\mathbf{k}$ et al. 1981) the inoculations in our study were made from samples of the brain hemispheres, liver and spleen. In most cases pooled samples were used so that it was impossible to specify the organ from which $T$. gondii were isolated. In the 4 cats from which separate inoculations were made from 10 different sites the largest quantities of $T$. gondii were isolated from the brain hemispheres, heart and liver. These findings are in keeping with the observations of $B \circ c h$ (1973) and $D u b \in y$ (1977) who reported that, besides the isolation from the CNS, the most frequent $\underline{T}$. gondii isolations were made from the heart. 
Gross pathological findings (miliary necroses in the liver, etc.) were found in only 2 kittens that excreted $T$. gondii oocysts in the faeces. Therefore gross pathomorphological changes in cats and dogs with toxoplasmosis can be regarded as rare and their incidence can be expected mainly in the acute stage of the disease. On the other hand, the direct demonstration of $T$. gondii tissue cysts in the brain tissue was not accompanied by any gross changes and is suggestive of chronic toxoplasmosis.

In conclusion it can be stated that isolation attempts on toxoplasma-negative white mice are an effective tool for demonstration of $T$. gondii developmental stages particularly in cats. Negative gross findings and negative results of histological examination of the brain, on the other hand, are not sufficient to exclude the possibility of toxoplasmosis.

\section{Postmortální diagnostika toxoplazmózy kočky a psa}

$\mathrm{V}$ průběhu 5 let jsme postmortálně vyšetřili na toxoplazmózu 161 kočku a 101 psa, kteř́ uhynuli nebo byli utraceni na klinice chorob malých zvírat Vysoké školy veterinární v Brně. Mikroskopickým vyšetřením kompresních preparátů $\mathrm{z}$ různých částí mozku a následným barvením jsme tkáňové cysty Toxoplasma gondii prokázali u 4 koček $\left(2,48 \frac{\circ}{0}\right)$. Izolační pokus na toxoplazma negativních bílých maších jsme vyhodnotili u 150 koček a 101 psa. Př́tomnost T. gondii jsme prokázali u 17 koček (11.33 \%) ve věku do 3 let a jednoho osmiletého psa $(0.99 \%)$. V největším počtu byla $\underline{T}$. gondii izolována z mozku, srdce a jater. Makroskopicky zjevné miliární nekrózy jater byly prokázány u 2 koček.

Průkaz vývojových stadií T. gondii izolačním pokusem na toxoplazma-negativních bílých maších byl několikanásobně efektivnější ve srovnání s mikroskopickým vyšetřením kompresních preparátů $\mathrm{z}$ rủzných částí mozku a makroskopickými změnami $\mathrm{v}$ játrech.

Посмертная диагностика токсоплазмоза кошки и собаки

В течение

пятилетнего

периода

проводили постмортальные исследования токсоплазмоза 161 кошки 
У 101 собаки, погибших или умерщвленных в клинике заболеваний мелких животных Ветеринарного института в Брно. Микроскопическим исследованием компрессных препаратов разных частей головного мозга последующей окраской тканевые кисты тохорlasma gondii были Установлены у 4 кошек $\left(2,48 \frac{7}{\%}\right)$. Изоляционный эксперимент на токсоплазма негативных белых мышах оценивали У 150 кошек и 101 собаки. Наличие $\mathrm{T}$. gondii было нами Установлено у 17 кошек $\left(11,33 \frac{\text { \% }}{\%}\right.$ в возрасте до 3 лет и одной восъмилетней собаки $(0,99 \%)$. В самом большомколичестве Т. gondii изолировали в головном мозгу, сердце и печени. Макроскопически явные милиарные некрозы печени были установлены Y 2 кошек.

Определение стадий развития T. gondii изоляционным экспериментом на токсоплазма негативных белых мышах было более эффективным в несколько раз по сравнению C микроскопическим исследованием препаратов разных частей головного компрессных макроскопическими изменениями печени.

$$
R \text { e f e r e n c e } s
$$

BOGDANJUK, D. S.: K voprosu o mechanisme razvitija infekcionogo procesa pri toksoplazmoze s učetom biologičeskich svojstv toksoplazm. In: Problemy parazitologii, Tr. VII. nauč. konf. parazitolog., Kijev, 1972: $90-91$. BCOH, J.: Toxoplasma- und Sarcocystis-Infektionen der Haustiere. Wien. tierärzt1. Mschr., 60, 1973: 337 - 341 .

COSTA, A. J. - ARAUJO, F. G. - COSTA, J. O. - LIMA, J. - NASCIMENTO, E.: Experimental infection of bovines with oocysts of Toxoplasma gondii. J. Parasitol., 63, 1977: 212 - 218.

DISKO, R. - BRAVENY, I. - GREUTELAERS, M. T. : Tierexperimentelle Untersuchungen zur Organaffinität von Toxoplasma gondii. Zb1. Bakt. Parasitenk. Infektionskrank. Hyg., 242, 1978: 565 - 571 .

DOBOS-KOVÁCS, M. - KARDEVÁN, A.: A kutya generalizárt toxoplasmosisäró1. Magy. állatorv. Lap., 26, 1976: $53-61$.

DUBEY, J. P.: Toxoplasma, Hammondia, Besnoitia, Sarcocystis, and Other Tissue Cyst-forming Coccidia of Man and Animals. In: Parasitic Protozoa (Kreier, J. P., editor) Academic Press Inc., New York 1977, vo1. 3., pp. $101-237$.

DUBEY, J. P. - JOHNSTONE, I.: Fatal Neonatal Toxoplasmosis in Cats.' J. Amer. Animal Hospital Assoc., 18, 1982: $461-467$.

HAGIWARA, T.: Toxoplasmos is of animals in Japan. Int. J. Zoon., 4, 1977: $56-70$.

HEJLfČEK, K. - PROSEK, F. - TREML, F.: Isolation of Toxoplasma gondii in free-living sma11 mammals and birds. Acta vet. Brno, 50, 1981: $233-236$.

HUUNER, J. - UHLIKOVÂ, M.: Use of the microprecipitation method in agar ge1 (MPA) in the diagnostics of toxoplasmosis, 3. Correlation of MPA, complement-fixation reaction (CFT) and Sabin-Feldman's dye test (SFT) in serodiagnosis of human toxoplasmosis. J. Hyg. Epidemiol. Microbio1. Immuno1., 17, 1973: $70-84$.

KOUBA, K. - JIRA, J. - HUUBNER, J.: Toxoplazmóza. 1st edition, Avicenum Praha, 1974: 306 p. 
MEINGASSNER, J. G. - MATTHAEI, C. - TEUTSCH, H. F.: Histochemische Untersuchungen zum Kohlenhydratstoffwechsel der Zystenstadien von Toxoplasma gondii. Z. Parasitenkde, 51, 1977: 219 - 228.

NESBIT, J. W. - LOURENS, D. C. - WILLIAMS, M. C.: Spastic paresis in two littermate pups caused by Toxoplasma gondii. J. S. Afr. veter. Assoc., 52, 1981: 243 - 246 .

NIEBERLE, G. - COHRS, P.: Lehrbuch der speziellen pathologischen Anatomie der Haustiere. 5. Auflage, G. Fischer, Jena 1970: 1286 p.

PARKER, G. A. - LANGLOSS, J. M. - DUBEY, J. P. - HOOVER, E. A.: Pathogenesis of Acute Toxoplasmosis in Specific-Pathogen-Free Cats. Veter. Path., 18, 1981: $786-803$.

WARD, J. M. - NELSON, N. - WRIGHT, J. F. - BERMAN, E.: Chronic clinical cerebral toxoplasmosis in cats. J. Amer. veter. med. Assoc., 159, 1971: 1012 - 1014. 